International Journal of Instruction e-ISSN: 1308-1470 • www.e-iji.net

Article submission code: 20191118152713

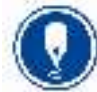

January $2021 \bullet$ Vol.14, No.1

p-ISSN: 1694-609X

pp. $105-120$

Received: 18/11/2019

Revision: 07/06/2020
Accepted: 27/06/2020

OnlineFirst: 10/10/2020

\title{
Development and Validation of Indonesian Academic Resilience Scale Using Rasch Models
}

\section{Ramdani Ramdani}

Universitas Negeri Malang, Indonesia, ramdani170111942015@student.um.ac.id, ramdanidani146@gmail.com

\section{Fattah Hanurawan}

Universitas Negeri Malang, Indonesia, fattah.hanurawan.fppsi@um.ac.id

\section{Ramli}

Universitas Negeri Malang, Indonesia, m.ramli.fip@um.ac.id

Blasius Boli Lasan

Universitas Negeri Malang, Indonesia, blasiusbolilasan@yahoo.co.id

\section{Afdal Afdal}

Universitas Negeri Padang, Indonesia, afdal@konselor.org

$$
\begin{aligned}
& \text { This study aims to develop and validate a scale to measure student academic } \\
& \text { resilience on junior high school level. The sample in this study was } 865 \text { junior high } \\
& \text { school students spreading across various regions in Indonesia. The methodology } \\
& \text { used in this research was quantitative, using a questionnaire with a 4-point Likert } \\
& \text { scale. The data analysis used the Rasch model, "i.e." Winsteps software. Analysis } \\
& \text { shows that the respondent's reliability index is } 0.78 \text { while the item reliability index } \\
& \text { is } 0.90 \text {. The item polarity angle indicates that each item can contribute to student } \\
& \text { academic resilience because the point-measure correlation value of each item } \\
& \text { between } 0.49 \text { to } 0.75 \text {. The item ideality test in the instrument shows that the outline } \\
& \text { of the item can be used. The research instruments in this study show that it } \\
& \text { measured what it should. The differential item functioning test shows that there } \\
& \text { were no items that had a bias in assessing the level of student academic resilience. } \\
& \text { The items in Indonesian academic resilience scale on junior high school level have } \\
& \text { high validity and reliability so that they can be used to measure the academic } \\
& \text { resilience of junior high school students. }
\end{aligned}
$$

Keywords: validate a scale, student academic resilience, high school student, academic resilience scale, Rasch Models

Citation: Ramdani, R., Hanurawan, F., Ramli, M., Lasan, B. B., \& Afdal, A. (2020). Development and Validation of Indonesian Academic Resilience Scale Using Rasch Models. International Journal of Instruction, 14(1), 105-120. https://doi.org/10.29333/iji.2021.1417a 


\section{INTRODUCTION}

The transition phase of schools from elementary to junior high school tends to be vulnerable to dealing with difficulties and challenges related to academic life, development, and social life. The academic life of students who have poor ability to adapt to difficulties, challenges, and failures will tend to experience psychological problems (Suranata, 2015). Now, the problems faced by the students are more complex than they were, thus students' abilities are required to solve complex problems. In solving the complex problem, the students should relate the previous learned concepts to solve it (Hobri, 2020). This can have an impact on hampering optimal achievement, stunted development, and more serious psychological problems (Gillham et al., 2007; Hidayah et al., 2016).

Students' abilities are needed to be able to succeed and obtain good academic results during academic and social life situations that are at risk. It influences the choice of activities individuals make, the effort they invest, and how long they will persist in stressful situations (Alkharusi et al., 2017; Ramdani et al., 2020). These allows the students to be able to face many difficulties, challenges, and obstacles (Banatao, 2011; Hidayah et al., 2016; Stiles et al., 2016). Those abilities are known as academic resilience.

Resilience generally leads to positive adaptation patterns during or after facing difficulties or risks. Resilience is the capacity to be able to respond, survive, or successfully develop themselves to master situations that are under pressure or threat (Rutter, 2012). In the field of education, academic resilience is seen as students' positive capacity to be able to achieve academic success, career development, and social life (Banatao, 2011; Martin et al., 2013; Nicoll, 2014).

Some studies indicate that students with high levels of resilience show better academic achievement (Dotterer and Lowe, 2011; Hanson and Kim, 2007; Kwok et al., 2007; Sagone and Elvira, 2014). In addition, other studies indicate that students with high levels of resilience show psycho-social and emotional development better than other students who have lower levels of resilience (Calkins et al., 2007; Smith and Zautra, 2008; Stiles et al., 2016).

There are some scales that can be used to measure the level of academic resilience of students (Stiles et al., 2016). However, nowadays, Indonesian researchers find only few scales that specifically address academic resilience. In this case, researchers use a general resilience measurement scale which is then adapted and adjusted to the measurement requirements (Rutter, 2012).

One of the scales for measuring students' academic resilience is the scale on The Resilience and Youth Development Module. The resilience scale is developed to measure general resilience in adolescence (Hanson and Kim, 2007). The scale on The Resilience and Youth Development Module measures adolescent resilience to their personal and social problems (Hanson and Kim, 2007).

The scale of resilience measurement cannot be used directly to measure academic resilience because it is still general. However, it is suitable for adaptation and use for 
students who are at the stage of adolescent development. The concept of resilience is one and universal, because of its different implementation and the existence of human life in different cultures. However, the difficulties faced will be different (Sagone and Caroli, 2014). The scale also needs to be adjusted to the academic life with regard to social and student learning and validated to be used in Indonesia (Suranata, 2015).

A fundamental difficulty in measurement in social science and psychology is how to carry out a quantitative weighting of latent qualitative phenomena (Andrich and Pedler, 2019). These phenomena include attitudes, character, personality, and academic resilience. Measurements in psychological studies show $95 \%$ of them are still being developed based on the Classical Test Theory (CTT) approach (Rachman and Napitupulu, 2017). CTT rests on the assumption that the visible score (X) is the sum of pure scores $(\mathrm{T})$ and errors (E). This error refers to various situational conditions that cannot be controlled, such as fatigue, environmental settings, etc. (Rachman and Napitupulu, 2017).

The Rasch model in developing social science measurement tools is a response to various weaknesses of the CTT paradigm (Andrich and Pedler, 2019). In the Rasch Model, raw data cannot be directly analyzed since they must first be converted into an 'odds ratio' to then transform logarithms into logit units as manifestations of the probability of respondents responding to an item (San Martín and Rolin, 2013). Through the Rasch model, an ordinal response can be transformed into a ratio that has a higher degree of accuracy by referring to the principle of probability (Briggs, 2019; Rachman and Napitupulu, 2017).

Thus, this study aims to develop and validate academic resilience scale that can measure student academic resilience on junior high level by adapting the indicators of resilience in the scale on The Resilience and Youth Development Module. The scale developed can be used as an assessment instrument to intervene (Nicoll, 2014). Furthermore, the student academic resilience scale on junior high school level will be validated using the Rasch Model to produce more holistic information about the instrument and better meet the definition of measurement (Briggs, 2019; Rachman and Napitupulu, 2017). The scale of academic resilience is expected to be used and following the background conditions in Indonesia.

\section{METHOD}

\section{Research Respondents}

A total of 865 students from several junior high schools in Indonesia participated in this study. Respondents came from eighteen schools in some regions in Indonesia. The respondents consisted of 345 male $(45 \%)$ and 520 female $(55 \%)$ students ranging from 13 to 15 years old, the average age was $14(\mathrm{SD}=0.9)$. The respondents' first language is Indonesian. All respondents participated voluntarily and received an explanation of the research objectives provided by researchers through the school and the names of respondents were coded to maintain respondents' confidentiality.

\section{Research Instruments}

The instrument used was a questionnaire with six measurement constructs consisting of thirty items. A questionnaire was developed under the theory, research, and available 
literature (Baghaei, 2011; Tabatabaee-Yazdi et al., 2018). The six measurement constructs used are indicators of student competencies, abilities, and skills that describe high academic resilience including social skills, empathy, problem-solving, self-efficacy, self-awareness, and positive aspirational goals (Benard, 2004). Three experts specializing in academic endurance carried out two cycles of revising the developed instrument. Some students were also invited to provide feedback and suggestions for the instruments developed. The instrument was then discussed again with the research team to examine the latest version of the instrument. The instrument developed was a questionnaire with a 4-point Likert scale. The choice of answers starts from Very Appropriate, Appropriate, Incompatible, and Extremely Unsuitable

Measurement of item reliability indicates the level of suitability of the item (fit) to the Rasch measurement model. This means that the items being embraced can be relied upon and the number of items are sufficient to measure a construct. The reliability index of items received is $>0.8$ (Bond and Fox, 2007). Table 1 shows that the social skills construct reliability index for items is 0.90 , empathy for items is 0.93 , problem-solving for items is 0.87 , self-efficacy for items is 0.89 , self-awareness for items is 0.91 , and positive aspiration goals for items is 0.87 . This shows that the questionnaire has good reliability.

Table 1

Reliability Analysis

\begin{tabular}{|c|c|c|c|c|c|c|c|}
\hline \multirow[b]{2}{*}{ No } & \multirow[b]{2}{*}{ Construct } & \multirow[b]{2}{*}{$\begin{array}{l}\text { Item } \\
\text { Reliability }\end{array}$} & \multirow[b]{2}{*}{ Isolation } & \multicolumn{2}{|c|}{ INFIT MNSQ } & \multicolumn{2}{|c|}{ OUTFIT MNSQ } \\
\hline & & & & $\operatorname{Max}$ & Min & $\operatorname{Max}$ & Min \\
\hline & & 0.90 & 3.95 & 1.17 & 0.77 & 1.17 & 0.79 \\
\hline 2 & Empathy & 0.93 & 3.32 & 1.14 & 0.90 & 1.15 & 0.90 \\
\hline 3 & Problem Solving & 0.87 & 4.51 & 1.19 & 0.74 & 1.18 & 0.76 \\
\hline 4 & Self-Efficacy & 0.89 & 4.40 & 1.17 & 0.75 & 1.17 & 0.78 \\
\hline 5 & Self-Awareness & 0.91 & 3.21 & 1.15 & 0.75 & 1.14 & 0.79 \\
\hline 6 & Aspiration Goals & 0.87 & 4.42 & 1.18 & 0.73 & 1.17 & 0.77 \\
\hline
\end{tabular}

\section{Analysis of the Rasch model}

To determine the quality of research instruments, the validity and reliability of measuring instruments need attention to determine the ability of the item (Bond and Fox, 2007). Data analysis for testing the instrument used Rasch model analysis software, “i.e." Winsteps version 3.73. Georg Rasch developed an analysis model of item response theory (or Item Response Theory, IRT) in 1960s, which was later popularized by Ben (Linacre, 2009). The Rasch model can see interactions between respondents and items at once. In the Rasch model, a value is not seen based on the raw score, but rather a logit value that reflects the probability of selecting an item on a group of respondents. This is used as an anticipation of the raw score of the Likert rating in the form of an ordinal which does not have the same interval among the scores (San Martín and Rolin, 2013). Psychometric devices used in this study include reliability at the instrument level (respondents and items), respondent and item validity, instrument unidimensionality, detection of bias on items and accuracy of the number of responses used 
Item validity refers to the polarity of an item. In determining the polarity of an item, the point-measure correlation (PTMEA CORR) point-size correlation coefficient is used. If the PTMEA CORR value is high of more than 3.8 (Arifin et al., 2010) or have index value is from 0.20 to 0.79 (Linacre, 2009), then an item can differentiate abilities among respondents. A negative or zero value indicates the interwoven response for an item or respondent is contrary to the variable or construct (Linacre, 2009).

To find out which items are not suitable, it can be seen from the value of means- square (MNSQ). Linacre (2009) explains the accuracy of items can be seen from the ideal item through MNSQ value. According to Boone et al., (2014), the value of means-square outfit, z-standard outfit, and point measure correlation are the criteria used to see the level of appropriateness of items. If the item does not meet the criteria, it is better if the item is repaired or replaced. Guidelines for assessing item conformity criteria according to Bone et al., (2014) are these:

1. Outfit Mean Square (MNSQ) value received: $0.5<\mathrm{MNSQ}<1.5$

2. Z-standard outfit values (ZSTD) received: $-2.0<$ ZSTD $<+2.0$

3. Point Measure Correlation value received: $0.4<\mathrm{pt}$ measure corr $<0.8$ Linacre (2009) claimed that the item MNSQ fell within the 0.5 to 1.5 range, In addition, it can also be known by adding up the mean value of the middle squared infit (mean MNSQ Infit) (Bambang and Widhiarsono, 2013). Indicating adequate fit, Bambang \& Widhiarsono (2013) gives MNSQ value categories as item accuracy, which is between $0.4-1.4$ for instruments with a Likert scale.

Next, look at the level of difficulty of each item. One of the special features of Rasch's analysis with Winstep is the existence of a map that illustrates the distribution of the subject's abilities and the distribution of the level of difficulty of items of the same scale. This map is called the Wright Map which is nothing but a person-item map. values on this map are arranged based on measure values ie values will usually range from -3 to +3 . But the value in this case logit values above 2 or below -2 can already be considered as extreme values. Sumintono and Widhiarso (2015) provide guidance in assessing these items into four categories, namely:

1. Measure value $<-1=$ very easy item

2. Measure value -1 to.d. $0=$ easy items

3. Measure value 0 to $1=$ difficult item

4. Measure value $>1=$ very difficult item

Unidimensionality analysis uses Principal Component Analysis (PCA) of the residual procedure allows the measurement model (Baghaei, 2011). Rasch recognizes one side factor that may pose a threat to unidimensional. According to (Baghaei and Aryadoust, 2015), the value of unexplained variance in the first construct residual PCA $>15 \%$ is weak, $10-15 \%$ is sufficient, $5-10 \%$ is strong, $3-5 \%$ is very strong, and less than $3 \%$ is special.

\section{FINDINGS}

The academic resilience scale on junior high school student level is divided into six measurement constructs used, namely social skills with 5 items, empathy with 5 items, problem-solving with 6 items, self-efficacy with 5 items, self-awareness with 6 items, and positive aspirational goals with 3 items. 


\section{Item Validity, and Item Ideality (Fit) Items}

Table 2 shows that there is one item that needs to be discarded and has four items that need to be considered. In the original results, the output has been ordered by Winstep based on the difficulty level. But the researchers edited and re-ordered the items in order. the order of difficulty levels can be seen on the wirght map. A measure score indicates the difficulty level of our item. The MNSQ infit-outfit shows whether our items are fit according to the Rasch model. PTMEA CORR stands for Point Measure Correlation, or is almost the same as point-biserial correlation in classical test theory. This parameter shows the power of discrimination ietm.

Table 2

Validity Item and Ideality Model (Fit) Item

\begin{tabular}{|c|c|c|c|c|c|c|}
\hline Construct & Item & $\begin{array}{l}\text { Score } \\
\text { Measure }\end{array}$ & $\begin{array}{l}\text { Model } \\
\text { S.E }\end{array}$ & $\begin{array}{l}\text { Infit } \\
\text { MNSQ }\end{array}$ & $\begin{array}{l}\text { Outfit } \\
\text { MNSQ }\end{array}$ & PTMEA CORR \\
\hline \multirow[t]{5}{*}{ Social skills } & K1 & -0.31 & 0.13 & 1.10 & 1.23 & 0.52 \\
\hline & $\mathrm{K} 2$ & -0.37 & 0.13 & 0.70 & 0.70 & 0.65 \\
\hline & K3 & -0.55 & 0.13 & 0.58 & 0.58 & 0.72 \\
\hline & K4 & -0.39 & 0.13 & 0.92 & 0.91 & 0.62 \\
\hline & K5 & 0.15 & 0.13 & 1.06 & 1.15 & 0.49 \\
\hline \multirow[t]{5}{*}{ Empathy } & E1 & 0.17 & 0.12 & 0.90 & 0.92 & 0.56 \\
\hline & E2 & 0.15 & 0.11 & 0.89 & 0.88 & 0.60 \\
\hline & E3 & 0.09 & 0.11 & 0.98 & 0.98 & 0.57 \\
\hline & $\mathrm{E} 4$ & -0.30 & 0.12 & 0.78 & 0.77 & 0.58 \\
\hline & E5 & 0.07 & 0.11 & 1.14 & 1.10 & 0.50 \\
\hline \multirow[t]{6}{*}{ Problem Solving } & PM1 & 0.12 & 0.11 & 1.10 & 0.97 & 0.48 \\
\hline & PM2 & -0.35 & 0.16 & 1.10 & 1.25 & 0.54 \\
\hline & PM3 & -0.45 & 0.16 & 0.70 & 0.72 & 0.67 \\
\hline & PM4 & -0.58 & 0.16 & 0.60 & 0.60 & 0.74 \\
\hline & PM5 & -0.45 & 0.16 & 0.94 & 0.93 & 0.64 \\
\hline & PM6 & 0.18 & 0.14 & 1.08 & 1.17 & 0.51 \\
\hline \multirow[t]{6}{*}{ Self-Efficacy } & ED1 & 0.21 & 0.14 & 0.92 & 0.94 & 0.58 \\
\hline & ED2 & 0.25 & 0.14 & 1.21 & 0.90 & 0.62 \\
\hline & ED3 & 0.10 & 0.14 & 0.98 & 0.97 & 0.59 \\
\hline & ED4 & -0.34 & 0.15 & 0.80 & 0.79 & 0.60 \\
\hline & ED5 & 0.21 & 0.14 & 1.16 & 1.12 & 0.52 \\
\hline & ED6 & 0.14 & 0.16 & 1.00 & 0.99 & 0.50 \\
\hline \multirow[t]{6}{*}{ Self-Awareness } & KD1 & -0.37 & 0.16 & 1.13 & 1.16 & 0.55 \\
\hline & $\mathrm{KD} 2$ & -0.39 & 0.16 & 0.73 & 0.73 & 0.68 \\
\hline & KD3 & -0.59 & 0.16 & 0.61 & 0.61 & 0.75 \\
\hline & KD4 & -0.40 & 0.16 & 0.95 & 0.94 & 0.65 \\
\hline & KD5 & 0.19 & 0.14 & 1.09 & 1.18 & 0.52 \\
\hline & KD6 & 0.22 & 0.14 & 0.93 & 0.95 & 0.59 \\
\hline \multirow[t]{3}{*}{ Aspiration Goals } & TA1 & 0.22 & 0.14 & 0.92 & 0.61 & 0.62 \\
\hline & TA2 & 0.09 & 0.16 & 0.99 & 0.99 & 0.60 \\
\hline & TA3 & -0.35 & 0.15 & 0.81 & 0.80 & 0.61 \\
\hline Mean & & 0.00 & & 0.98 & & \\
\hline S.D & & 0.4 & & 0.18 & & \\
\hline
\end{tabular}

Item validity refers to the polarity of an item. In determining the polarity of an item, the PTMEA CORR point-size correlation coefficient is used. The results show the polarity of items in the construct of social skills was at 0.49 to 0.72 , the construct of empathy was at 0.50 to 0.60 , the construct of problem-solving was at 0.48 to 0.74 , the construct 
of self-efficacy was at 0.50 to 0.62 , the construct of self-awareness is at 0.52 to 0.75 , and the aspiration goal construct was at 0.51 to 0.62 . Following criteria recommended by Arifin et al., (2010) and Linacre, (2009), that the PTMEA CORR value must be higher than 3.8 or have an index value of 0.20 to 0.79 , it can be seen that all the item is appropriate.

Furthermore, to find out which items are not suitable and the accuracy of items can be seen from the ideal item through MNSQ value. Following the criteria recommended by Bond and Fox (2007) and Linacre (2009) the results show that all items fit the Rasch model. In addition, it can also be known by summing the average value of the middle square infit (mean MNSQ Infit) (Bambang and Widhiarsono, 2013) which is 0.98 with a standard deviation (MNSQ SD Infit), which is 0.81 , and the value is $0.98+0.18=1.16$; so the MNSQ Infit value greater than 1.16 is an indication of inappropriate items. Table 2 shows that ED2 items have an MSQ infil value of 1.21 or more than 1.16, so the item needs to be deleted even though it has a value that is in accordance with previously recommended criteria.

As seen in Table 2, the average logit value of the item is 0.0 logit, which indicates that the instrument as a whole can be used as a measurement. The average value of a logit 0.0 item is a random value set to express the probability of 50:50 which is nothing, but the same measure between the respondents' ability level and the difficulty level of the problem (Bond and Fox, 2007). If it is found that the average logit of the item is not 0.0, then the overall instrument is not good.

If it is seen further, some items had almost the same logit value, both of which originated from the same construct, namely PM3 items (logit 0.45) and PM5 items (logit 0.45), and ED1 items (Logit 0.21) and ED5 items (Logit 0.21). This provides information that the item measured the same thing, so there was no need to bring up to two items (Bambang and Widhiarsono, 2013). Simplification of the item was then made by simply selecting one of them.

Next the distribution of the subject's abilities and the distribution of the level of difficulty of items can be look at the level of difficulty of each item at Wright Map at figure 1 .

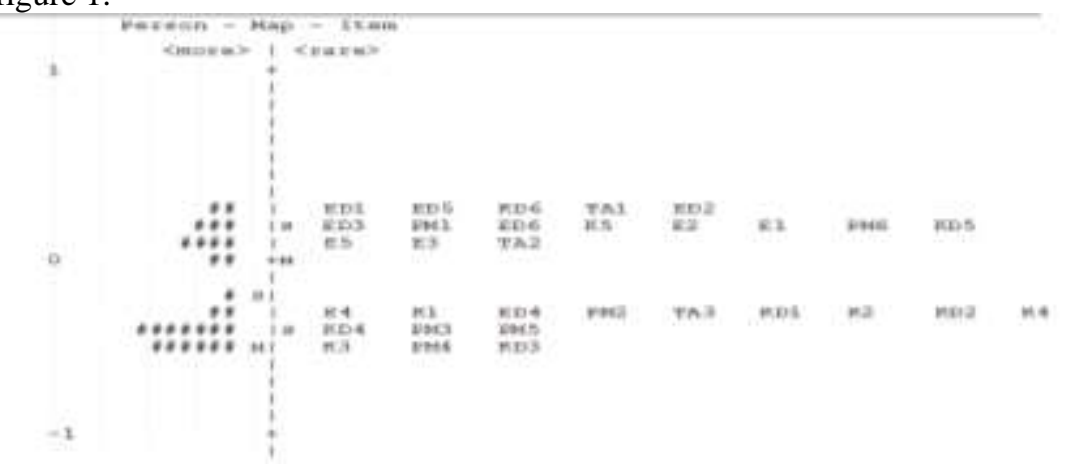

Figure 1

Person Map Item 
Figure 1 represents the Item-person map of the data (a section of the map is shown because of its long length). Numbers on the right indicate items and \# on the left signify persons. Items and persons located on top of the scale are more difficult and more proficient, respectively. On the other hand, items down the scale are easier and less proficient. The lowest threshold is -0.59 logits (item KD3) and the highest is 0.25 logits (item ED2). Theoretically, every subject has the opportunity to answer correctly every question in the instrument because it has abilities that tend to be equivalent to the level of difficulty in each of these questions.

From the whole item on the Student Academic Resilience Scale on junior high school level, there was one item needed to be discarded and four items originating from the two constructs must be reviewed to be simplified. This was because the item gave the same response pattern as the other items in the same construct, so it needed to be reviewed and simplified.

\section{Unidimensionality Test}

One of the most important considerations in designing a measurement is to guarantee that the measurement tool is unidimensional. Unidimensionality is important to know whether it is measuring what should be measured. Unidimensionality considers items in the measuring instrument to measure a single ability (Baghaei, 2013, Tabatabaee-Yazdi et al., 2018). This model provides a brief procedure for checking the dimension of a measuring instrument. Basic component analysis based on PCA in the residual procedure allows the Rasch measurement model to recognize a side factor that might be a threat to unidimensional (Baghaei and Aryadoust, 2015). Table 3 shows the measurement tools both for constructing social skills, empathy, problem-solving, selfefficacy, self-awareness, and positive aspiration goals measuring one dimension, where the raw data variance of social skills of $52 \%$, empathy of $54 \%$, problem-solving of $50 \%$, self-efficacy of $53 \%$, self-awareness of $51 \%$, and positive aspiration goals of $51 \%$.

Table 3

Unidimensionality Test

\begin{tabular}{llllll}
\hline No & Construct & $\begin{array}{l}\text { Variance explained by } \\
\text { measures }(\%)\end{array}$ & $\begin{array}{l}\text { unexplained } \\
\text { construct }\end{array}$ & variance in & 1st \\
\hline 1 & Social skills & 52 & $11.7 \%$ & & \\
2 & Empathy & 54 & $8.2 \%$ & & \\
3 & Problem Solving & 50 & $7.6 \%$ & & \\
4 & Self-Efficacy & 53 & $80 \%$ & & \\
5 & Self-Awareness & 51 & $10.8 \%$ & & \\
6 & Aspiration Goals & 51 & $10.5 \%$ & & \\
\hline
\end{tabular}

The table above shows the minimum requirements of $20 \%$ unidimensionality are met and simultaneously the Rasch unidimensional limit is fulfilled, i.e. above $40 \%$ (Linacre, 2009). Unexplained variance all under $20 \%$ shows the level of independence of the item in a good instrument. 


\section{Differential Item Functioning (DIF) Based On Gender}

Differential Item Functioning (DIF) aims to test whether the items given have bias or not in the category of gender respondents. A good item should not be biased during the measurement process. The analysis of the Rasch model shows this in terms of the DIF. Items that have a bias can be known with a probability value below $5 \%(0.05)$ (Bambang and Widhiarsono, 2013). Some author also used a chi-square test to detect DIF (Le, 2009).

Table 4

Differential Item Functioning

\begin{tabular}{|c|c|c|c|c|c|c|c|c|}
\hline Gender & $\begin{array}{l}\text { DIF } \\
\text { Measure }\end{array}$ & Gender & $\begin{array}{l}\text { DIF } \\
\text { Measure }\end{array}$ & $\begin{array}{l}\text { DIF } \\
\text { Contrast }\end{array}$ & DIF $\mathrm{t}$ & $\mathrm{P}$ & Item & Construct \\
\hline Male & -0.36 & Female & -0.36 & 0.05 & 0.05 & 0.45 & K1 & Social skills \\
\hline Male & -0.36 & Female & -0.36 & 0.01 & 0.01 & 0.80 & $\mathrm{~K} 2$ & \\
\hline Male & -0.47 & Female & -0.32 & -0.17 & -1.20 & 0.55 & $\mathrm{~K} 3$ & \\
\hline Male & -0.32 & Female & -0.17 & -0.15 & -1.15 & 0.25 & K4 & \\
\hline Male & 0.08 & Female & 0.03 & 0.06 & 0.45 & 0.85 & K5 & \\
\hline Male & -0.08 & Female & 0.10 & -0.17 & -1.48 & 0.15 & E1 & Empathy \\
\hline Male & -0.13 & Female & -0.33 & 0.30 & 1.60 & 0.14 & E2 & \\
\hline Male & -0.07 & Female & 0.11 & -0.16 & -1.28 & 0.21 & E3 & \\
\hline Male & 0.05 & Female & 0.41 & -0.37 & -1.18 & 0.35 & E4 & \\
\hline Male & 0.14 & Female & 0.41 & -0.30 & -1.50 & 0.55 & E5 & \\
\hline Male & 0.09 & Female & 0.38 & -0.30 & -1.50 & 0.07 & PM1 & $\begin{array}{l}\text { Problem } \\
\text { Solving }\end{array}$ \\
\hline Male & -0.32 & Female & -0.17 & -0.15 & -1.15 & 0.25 & PM2 & \\
\hline Male & 0.05 & Female & 0.04 & 0.08 & 0.46 & 0.88 & PM3 & \\
\hline Male & -0.05 & Female & 0.10 & -0.13 & -1.30 & 0.18 & PM4 & \\
\hline Male & -0.15 & Female & -0.30 & 0.25 & 1.65 & 0.13 & PM5 & \\
\hline Male & -0.08 & Female & 0.06 & -0.17 & -1.21 & 0.23 & PM6 & \\
\hline Male & 0.04 & Female & 0.45 & -0.35 & -1.17 & 0.36 & ED1 & Self-Efficacy \\
\hline Male & 0.14 & Female & 0.48 & -0.22 & -1.57 & 0.62 & ED2 & \\
\hline Male & 0.08 & Female & 0.34 & -0.20 & -1.55 & 0.10 & ED3 & \\
\hline Male & 0.08 & Female & 0.04 & 0.06 & 0.45 & 0.89 & ED4 & \\
\hline Male & -0.08 & Female & 0.10 & -0.18 & -1.32 & 0.19 & ED5 & \\
\hline Male & -0.13 & Female & -0.38 & 0.24 & 1.65 & 0.14 & ED6 & \\
\hline Male & -0.07 & Female & 0.08 & -0.14 & -1.25 & 0.25 & KD1 & $\begin{array}{l}\text { Self- } \\
\text { Awareness }\end{array}$ \\
\hline Male & 0.08 & Female & 0.05 & 0.09 & 0.44 & 0.80 & $\mathrm{KD} 2$ & \\
\hline Male & -0.07 & Female & 0.07 & -0.14 & -1.39 & 0.19 & KD3 & \\
\hline Male & -0.20 & Female & -0.37 & 0.21 & 1.68 & 0.14 & KD4 & \\
\hline Male & -0.05 & Female & 0.05 & -0.19 & -1.21 & 0.25 & KD5 & \\
\hline Male & -0.30 & Female & -0.30 & 0.01 & 0.00 & 0.82 & KD6 & \\
\hline Male & -0.40 & Female & -0.36 & -0.12 & -1.25 & 0.56 & TA1 & $\begin{array}{l}\text { Aspiration } \\
\text { Goals }\end{array}$ \\
\hline Male & -0.37 & Female & -0.18 & -0.15 & -1.14 & 0.35 & TA2 & \\
\hline Male & 0.05 & Female & 0.05 & 0.02 & 0.45 & 0.85 & TA3 & \\
\hline
\end{tabular}

Table 4 shows that there are no items that have a bias because it is seen from the value of $p>0.05$. The absence of items that have a bias indicates that the gender factor as a differentiator in this measurement does not provide a bias in assessing the level of student academic resilience. However, at this stage, it cannot be ascertained and requires 
further research to be able to know more details about various things that can affect the measurement of students' academic resilience levels, some of which can come from ethnicity, parents' educational background, etc.

\section{DISCUSSION}

Overall, the student academic resilience scale on junior high school level has good validity and reliability. Therefore, it can be used to measure student academic resilience on junior high school level in the construct of social skills, empathy, problem-solving, self-efficacy, self-awareness, and positive aspiration goals. The social skills construct reliability index for items is 0.90 , empathy for items is 0.90 , problem-solving for items is 0.90 , self-efficacy for items is 0.90 , self-awareness for items is 0.90 , and positive aspiration goals for items is 0.90 . This shows the questionnaire has good reliability. Accordingly, Linacre (2009) endorse that the reliability value of items from 0.67 to 0.80 is categorized as simple, 0.81 to 0.90 is categorized as good, and $>0.91$ is very good. Meanwhile, the reliability index of items and respondents received was $\geq 0.8$ (Bond and Fox, 2007).

The results showed the polarity of the items of the entire construct was in the range of 0.48 to 0.75 . Following criteria recommended by Arifin et al., (2010) and Linacre, (2009), that the PTMEA CORR value must be higher than 3.8 or have an index value of 0.20 to 0.79 , it can be seen that all the item is appropriate. This means that the items contained are in that construct or, in other words, the items can measure the construct of academic resilience.

All items analyzed meet the range of values received. but further testing is needed to find out which items do not match. it is necessary to add the average value of the middle squared infusion (mean MNSQ infusion) 0.98 with a standard deviation (MNSQ infit SD). Table 2 shows that ED2 items have an MSQ infusion value of more than the sum between the average middle squared infusion (mean MNSQ Infit) of 0.98 with standard deviations (Infit MNSQ SD) so that the item needs to be deleted. This is in accordance with the recommendation of Bambang and Widhiarsono (2013) that the value of MNSQ Infit greater than the sum is an indication of inappropriate items. .

Furthermore, the measurement results show that the two items have almost the same logit value, both of them come from the same construct. This provides information that items measure the same thing, so there is no need to carry up to two items. this is in accordance with the recommendation of Bambang and Widhiarsono (2013) that the disposal of one item can be done if both measure the same thing. The item is then simplified by simply taking one of them.

Unidimensionality assumes that the items measured can measure a single effort. This model provides a concise procedure for checking the dimension of a measurement. Principal component of analysis based on PCA of the residual procedure allows the measurement model (Baghaei, 2011). Rasch recognizes one side factor that may pose a threat to unidimensional. According to (Baghaei \& Aryadoust, 2015), the value of unexplained variance in the first construct residual PCA $>15 \%$ is weak, $10-15 \%$ is sufficient, $5-10 \%$ is strong, $3-5 \%$ is very strong, and less than $3 \%$ is special. The value 
of unexplained variance in the first construct of all constructs is in the range of 7.6 to 11.7 indicating sufficient and strong indicators. The value of the variance size (Variance explained by measures) is best $>40 \%$. The results showed the value of PCA for the construct of social skills, empathy, problem-solving, self-efficacy, self-awareness, and aspiration goals was $>40 \%$ so that each item had measured the construct of academic resilience.

DIF aims to test whether the items given have bias or not in the category of gender respondents. Good items should not be biased during the measurement process (Bond \& Fox, 2007). Item infected with bias can be known by looking at the probability value below 5\% (0.05) (Bambang and Widhiarsono, 2013). Bias means that items cannot measure fairly in certain categories of respondents. Furthermore, DIF is significantly based on three indicator values namely t-value, DIF Contrast value, and p-value. The size of the $\mathrm{t}$-value lies on +2.0 or $\mathrm{t} \geq \pm 2.0$ to $\leq-2.0$, the DIF contrast index is at a value of \pm 0.5 to $\leq-0.5$ and the significant value for $p$ is $p>0.05$,

\section{Implication}

This academic resilience scale was developed specifically for junior high school students so that it has more capabilities compared to the academic resilience measurement scale already existed. In this academic resilience scale for junior high school students, each item is designed and adjusted to specifically measure the conditions of resilience in the academic field of students. This is certainly different from the previous scale of measurement which used a general item of resilience even though the constructs tend to be the same. School counselors can use this academic resilience scale instrument to identify the academic resilience profile of junior high school students in their workplace. This academic resilience scale can provide accurate information that can guide the school counselor in designing service programs or in providing services related to junior high school student academic resilience.

\section{CONCLUSION}

This paper presents research on the development and validation of the academic resilience scale on junior high school students. Six constructs were identified based on a literature review on academic resilience, where each construct contained items compiled in the instrument using a questionnaire with a 4-point Likert scale. A total of 865 junior high school students in Indonesia were randomly selected to fill out research instruments voluntarily.

The results of the research show that overall examination of items contained in academic resilience instruments using Rasch modeling has good validity and reliability. Therefore, this instrument can be used to measure academic resilience. Item test results show that one item (self-efficacy) did not meet the statistic requirements that had an MSQ infit value more than average even though the PTMEA CORR value exceeds 0.38 , so the item needed to be discarded. Furthermore, some items have almost the same logit value, both of which originate from the same construct (self-efficacy and problem solving) providing information that the items measure the same thing, so there was no need to 
bring up to two items. Simplification of the item was then made by simply selecting one of them.

The research instruments in this study fulfill the requirements of unidimensionality, so that they show their ability to measure what should be measured. Testing of DIF based on gender shows that the gender factor as a differentiator in this measurement does not provide a bias in assessing the level of student academic resilience. However, at this stage, it cannot be ascertained and requires further research to be able to know more details about various things that can affect the measurement of students' academic resilience levels, some of which can come from ethnicity, parents' educational background, etc.

From the whole items on the student Academic Resilience Scale on junior high school level, there was one item that needed to be discarded and four items originating from the two constructs must be reviewed to be simplified. This is because the item gives the same response pattern as the other items in the same construct, so it needs to be reviewed and simplified. The final results of the measurements that have been made produce twenty-seven items measuring the scale of student academic resilience on junior high school level.

One of the limitations of this study is that the researchers consider only students' academic resilience levels for junior high school students in Indonesia. thus, other studies could work on students' at high levels, different country and different culture to expand on the validation of the questionnaire with a broader examination in order to generalize the findings. Moreover, examining the scale using multidimensional Rasch model could be a significant future direction to study different constructs of the scale separately.

Academic resilience scales that have been developed and validated provide a new form of resilience scale that is specifically used to measure students' academic resilience levels. this is certainly different from the scale that had already existed which tends to be general in nature. In addition, this scale is specifically designed for junior high school students in Indonesia. The researcher recommends further research if it is used for higher education or its application outside of Indonesia.

\section{REFERENCES}

Andrich, D., \& Pedler, P. (2019). A law of ordinal random error: The Rasch measurement model and random error distributions of ordinal assessments. J of the Int Meas Confed, 131, 771-781. https://doi.org/10.1016/j.measurement.2018.08.062.

Alkharusi, H., Aldhafri, S., Al-Hosni, K., Al-Busaidi, S., Al-Kharusi, B., Ambusaidi, A., \& Alrajhi, M. (2017). Development and validation of a scale for measuring mathematics teaching self-efficacy for teachers in the sultanate of Oman. International Journal of Instruction, 10(3), 143-158. https://doi.org/10.12973/iji.2017.10310a.

Ariffin, R. S., Omar, B., Isa, A., \& Sharif, S. (2010). Validity and reliability multiple intelligent item using Rasch measurement model. Procedia - Social and Behavioral Sciences, 9, 729-733. https://doi.org/10.1016/j.sbspro.2010.12.225. 
Baghaei, P. (2011). Aplicación de modelos Rasch multidimensionales en la evaluación y validación a gran escala. Un ejemplo empírico. Electronic Journal of Research in Educational Psychology, 10(26), 233-252.

Baghaei, P. (2013). Development and psychometric evaluation of a multidimensional scale of willingness to communicate in a foreign language. European J of Psychology of Education, 28(3), 1087-1103. https://doi.org/10.1007/s10212-012-0157-y.

Baghaei, P., \& Aryadoust, V. (2015). Modeling local item dependence due to common test format with a multidimensional Rasch model. International Journal of Testing, 15(1), 71-87. https://doi.org/10.1080/15305058.2014.941108.

Bambang, S., \& Widhiarsono, W. (2013). Model Rasch untuk Penelitian Aplikasi TrimKom Publishing House.

Banatao. E. J. (2011). Educational resilience: The relationship between school protective factors and student achievement (Unpublished doctoral dissertation). San Diego State University. US.

Benard, B. (2004). Resiliency; What we have learned. WestEd.

Bond, T. G., \& Fox, C. M. (2007). Applying the Rasch model: Fundamental measurement. Lawrence Erlbaum Associates.

Boone, W. J., Staver, R. J., \& Yale, S. M. (2014). Rasch analysis in the human sciences. London: Springer.

Briggs, D. C. (2019). Interpreting and visualizing the unit of measurement in the Rasch Model. Measurem., 146, 961-971. https://doi.org/10.1016/j.measurement.2019.07.035.

Calkins, S. D., Blandon, A. Y., Williford, A. P., \& Keane, S. P. (2007). Biological, behavioral, and relational levels of resilience in the context of risk for early childhood behavior problems. Development and Psychopathology, 19(3), 675-700. https://doi.org/10.1017/S095457940700034X.

Dotterer, A. M., \& Lowe, K. (2011). Classroom context, school engagement, and academic achievement in early adolescence. Journal of Youth and Adolescence, 40(12), 1649-1660. https://doi.org/10.1007/s10964-011-9647-5.

Gillham, J. E., Reivich, K. J., Freres, D. R., Chaplin, T. M., Satte, A. J., Samuels, B., \& Litzinger, S. (2007). School-based prevention of depressive symptoms: A randomized controlled study of the effectiveness and specificity of the Penn Resiliency Program. Journal of Concutling and Clinical Psychology, 75(1), 9-19. https://doi.org/10.1037/0022-006X.75.1.9.School-Based.

Hanson, T. L., \& Kim, J.-O. (2007). Measuring resilience and youth development: The psychometric properties of the healthy kids survey (Rel 2007-No. 034). US: National Center for Education Evaluation and Regional Assistance, Institute of Education, U.S. Department of Education.

Hidayah, N. H., Pali, M., Ramli, M., \& Hanurawan, F. (2016). Students' well-being 
assessment at school. Journal of Educational, Health and Community Psychology, 5(1), 62. https://doi.org/10.12928/jehcp.v5i1.6257.

Hobri, Ummah, I. K., Yuliati, N., \& Dafik (2020). The effect of jumping task based on creative problem solving on students' problem solving ability. International Journal of Instruction, 13(1), 387-406. https://doi.org/10.29333/iji.2020.13126a.

Kwok, O. man, Hughes, J. N., \& Luo, W. (2007). Role of resilient personality on lower achieving first grade students' current and future achievement. Journal of School Psychology, 45(1), 61-82. https://doi.org/10.1016/j.jsp.2006.07.002.

Le, L. T. (2009). Investigating Gender differential item functioning across countries and test languages for PISA science items. International Journal of Testing, 9(2), 122-133. https://doi.org/10.1080/15305050902880769.

Linacre, J. M. (2009). Local independence and residual covariance: A study of olympic figure skating ratings. Journal of Applied Measurement, 10(2), 157-169.

Martin, A. J., Ginns, P., Brackett, M. A., Malmberg, L. E., \& Hall, J. (2013). Academic buoyancy and psychological risk: Exploring reciprocal relationships. Learning and Individual Differences, 27, 128-133. https://doi.org/10.1016/j.lindif.2013.06.006.

Nicoll, W. G. (2014). Developing transformative schools: A resilience-focused paradigm for education. International Journal of Emotional Education, 6(1), 47-65.

Rachman, T., \& Napitupulu, D. B. (2017). Rasch model for validation a user acceptance instrument for evaluating e-learning system. Communication and Information Technology Journal, 11(1), 9. https://doi.org/10.21512/commit.v11i1.2042.

Ramdani, R, Nasution, A. P., Ramanda, P., Sagita, D. D., \& Yanizon, A. (2020). Strategi Kolaborasi Dalam Manajemen Pelayanan Bimbingan Konseling di Sekolah. Educational Guidance and Counseling Development Journal. 3(1). 1-7.

Rutter, M. (2012). Resilience as a dynamic concept. Development and Psychopathology, 24(2), 335-344. https://doi.org/10.1017/S0954579412000028.

Sagone, E., \& Elvira De Caroli, M. (2014). A Correlational study on dispositional resilience, psychological well-being, and coping strategies in university students. American J of Edu Research, 2(7), 463-471. https://doi.org/10.12691/education-2-7-5.

San Martín, E., \& Rolin, J. M. (2013). Identification of parametric Rasch-type models. $J$ of Stat Plan. and Inference, 143(1), 116-130. https://doi.org/10.1016/j.jspi.2012.06.014

Smith, B. W., \& Zautra, A. J. (2008). Vulnerability and resilience in women with arthritis: Test of a two-factor model. Journal of Consulting and Clinical Psychology, 76(5), 799-810. https://doi.org/10.1037/0022-006X.76.5.799.

Stiles, T., Hjemdal, O., Friborg, O., \& Stiles, T. C. (2016). Resilience predicting psychiatric symptoms: A prospective study of protective factors and their role in adjustment to stressful life events. Clinical Psychology \& Psychotherapy, 13(3), 194 201. https://doi.org/10.1002/cpp.488. 
Suranata, K. (2015). Caring community as streng of an effort to develop the student resilience. 90-100. Gorontalo: Procceeding On International conference FIP-JIP Forum.

Sumintono, B., \& Widhiarso, W. (2015). Aplikasi Pemodelan Rasch pada Assessment Pendidikan. Cimahi: Trim Komunikata.

Tabatabaee-Yazdi, M., Motallebzadeh, K., Ashraf, H., \& Baghaei, P. (2018). Development and validation of a teacher success questionnaire using the rasch model. $\begin{array}{llll}\text { International } J & \text { of Instruction, } & 129-144 .\end{array}$ https://doi.org/10.12973/iji.2018.11210a.

\section{Attachment 1}

Academic Resilience Scale on Junior High School Student Level

The choice of answers starts from Very Appropriate, Appropriate, Incompatible, and Extremely Unsuitable

\begin{tabular}{|c|c|}
\hline \multicolumn{2}{|c|}{ Social Skills } \\
\hline \multirow[t]{2}{*}{1} & I can study together with other people who are not my age. \\
\hline & Saya dapat belajar bersama dengan orang lain yang tidak seusia dengan saya \\
\hline \multirow[t]{2}{*}{2} & I am firm in my position without disparaging others when learning something. \\
\hline & Saya teguh dengan pendirian saya tanpa meremehkan orang lain ketika mempelajari sesuatu \\
\hline \multirow[t]{2}{*}{3} & I can be calm when facing conflicts with friends when studying. \\
\hline & Saya dapat bersikap tenang saat menghadapi konflik dengan teman ketika belajar \\
\hline \multirow[t]{2}{*}{4} & I feel uncomfortable when I have to study together with friends I don't like. \\
\hline & $\begin{array}{l}\text { Saya merasa kurang nyaman ketika harus belajar bersama dengan teman yang tidak saya } \\
\text { senangi }\end{array}$ \\
\hline \multirow[t]{2}{*}{5} & I am not easy to forgive friends who do wrong to me in learning. \\
\hline & Saya tidak mudah memaafkan teman yang berbuat salah kepada saya dalam belajar \\
\hline \multicolumn{2}{|c|}{ Empathy } \\
\hline \multirow[t]{2}{*}{6} & I am able to understand the reason why the teacher gave me schoolwork. \\
\hline & Saya maтри memahami alasan guru memberikan saya tugas sekolah \\
\hline \multirow[t]{2}{*}{7} & I feel happy when my friends get achievements in class. \\
\hline & Saya ikut merasa senang ketika teman saya memperoleh prestasi di kelas. \\
\hline \multirow[t]{2}{*}{8} & I get emotional easily when the teacher gives advice in class. \\
\hline & Saya mudah terbakar emosi ketika guru memberikan nasehat di kelas \\
\hline \multirow[t]{2}{*}{9} & I do not care about the problems I face in learning. \\
\hline & Saya tidak peduli dengan masalah yang saya hadapi dalam belajar \\
\hline \multirow[t]{2}{*}{10} & I am upset when a friend asked me a problem lesson. \\
\hline & Saya kesal ketika teman bertanya masalah pelajaran kepada saya \\
\hline \multicolumn{2}{|c|}{ Problem Solving } \\
\hline \multirow[t]{2}{*}{11} & I am able to recognize the causes of the learning problems I face. \\
\hline & Saya mampu mengenali penyebab dari masalah belajar yang saya hadapi \\
\hline \multirow[t]{2}{*}{12} & I am able to introspect myself when facing problems in learning. \\
\hline & Saya mampu mengintrospeksi diri pada saat menghadapi masalah dalam belajar \\
\hline \multirow[t]{2}{*}{13} & I have difficulty in finding solutions to the problems I face when studying. \\
\hline & $\begin{array}{l}\text { Saya mengalami kesulitan dalam menemukan solusi atas masalah yang saya hadapi ketika } \\
\text { belajar }\end{array}$ \\
\hline \multirow[t]{2}{*}{14} & I am able to think positively when facing a problem in learning. \\
\hline & Saya maтри berpikir positif ketika menghadapi sebuah masalah dalam belajar \\
\hline \multirow[t]{2}{*}{15} & Other people are responsible for the failures I face at school. \\
\hline & Orang lain bertanggung jawab atas kegagalan yang saya hadapi di sekolah \\
\hline \multicolumn{2}{|c|}{ Self-Efficacy } \\
\hline
\end{tabular}




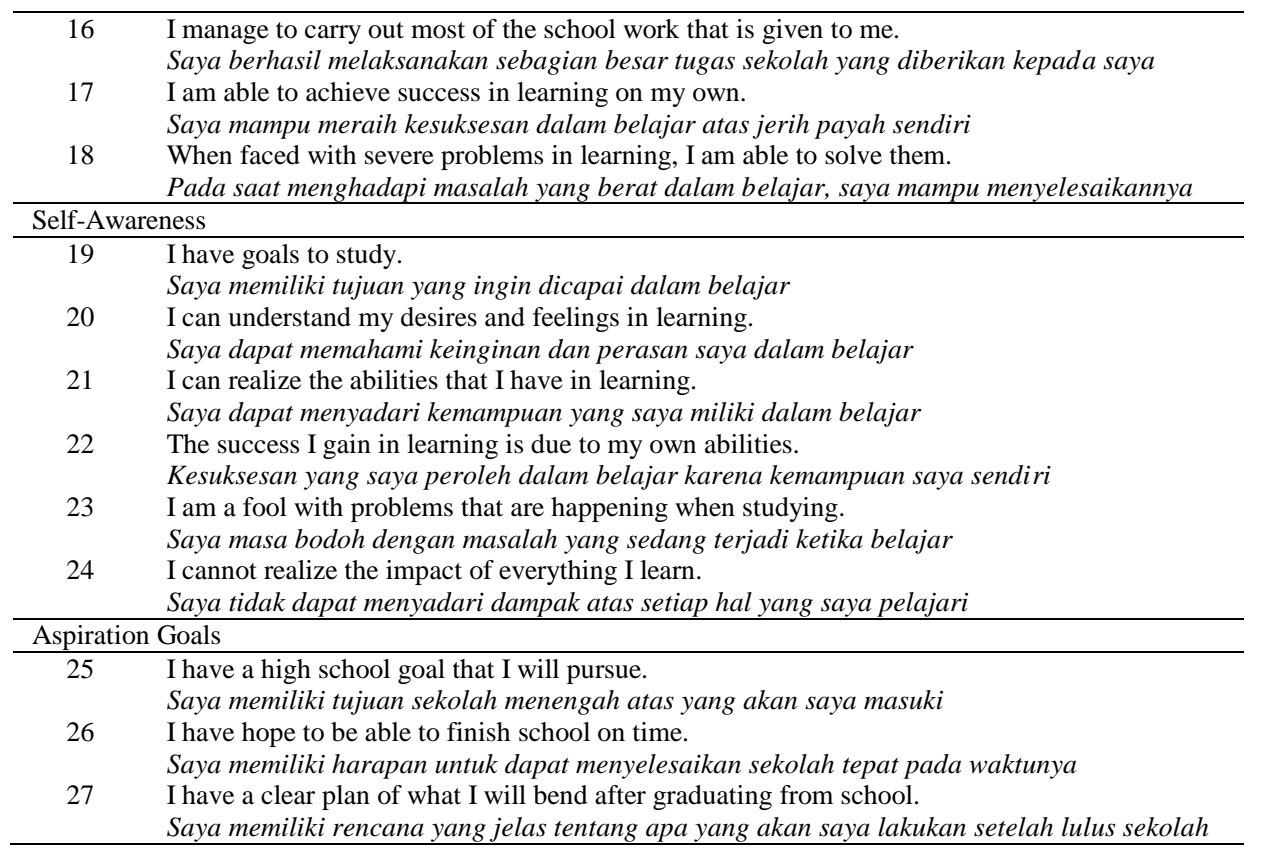

